\title{
E-Banking services quality and customer loyalty: The moderating effect of customer service satis- faction: Empirical evidence from the UAE banking sector
}

\author{
Mohammad Sleimi $^{\mathrm{a}^{*}}$, Mahmoud Musleh ${ }^{\mathrm{b}}$ and Ihab Qubbaj ${ }^{\mathrm{c}}$
}

${ }^{a}$ Head of Industirial Management Department, Palestine Technical University - Kadoorie, Palestine

${ }^{b}$ Near East University, Cyprus

${ }^{c}$ Assistant Professor, Palestine Technical University, Kadoorie, Palestine

\section{H R O N I C L E}

Article history:

Received: March 18, 2020

Received in revised format:

May 302020

Accepted: June 18, 2020

Available online:

June 19, 2020

Keywords:

Customer Satisfaction

E-Banking service quality

$U A E$

Customer Loyalty

\section{A B S T R A C T}

Despite the importance of the relationship between E-banking service quality and customer loyalty in the banking sector, little research has been devoted to Arabian regions. This paper investigates the relationship between e-banking service quality (i.e., efficiency, requirement fulfillment, accessibility and, Privacy) and customer loyalty by mediating customer satisfaction in UAE. Two steps sampling techniques are used and the researchers rely on cluster sampling in the region of Ras Al Khaimah (RAK) randomly. Again, random sampling techniques are used to choose 28 branches out-off the 34 branches operating within this geographic area. 1500 surveys are distributed and 397 valid surveys are collected with a response rate of $26.5 \%$. A partial least squares structural equation modeling (PLS-SEM) is applied to the data and the results show that the direct and indirect path coefficient between E-banking service quality and customer loyalty were statistically significant. Moreover, customer satisfaction mediates the relationship between E-banking service quality and customer loyalty. To sum up, the findings corroborate existing work in Western settings and underscore the importance of E-banking service quality in the Arabian banking context.

\section{Introduction}

In the business world, customer satisfaction is considered to be one of the most significant components of business success. The satisfaction of consumers guarantees earning their loyalty and their valuable recommendation to other potential customers which maintains stability for any other businesses. Though, satisfying customers is not like walking in the park and we need to provide our customers with the best services available in the market with creative and innovative solutions. According to the Middle East region, United Arab Emirates has become well known as a key financial hub, it owns the banking sector that is fragmented. The United Arab Emirates has 46 foreign and domestic banks that are operating. As the banking sector grew more widely and became a necessity in many people's daily lives, internet banking became important part of the service provided by the banks in UAE (Mansumitrchai \& Chiu, 2012). Hence, providing good and efficient E-banking services should be a priority to every bank in The UAE since that obviously directly affects customer satisfaction and loyalty. Internet banking or online banking is defined as an electronic payment system that enables bank's customers or any financial institution to manage a variety of payment transactions through the website of financial institution. This helps any customer check and make any transaction from any place without even visiting a branch of any bank, waiting in queue and wasting time. The research purposes of this study are analyzing the customer satisfaction level towards the quality of E-Banking services provided by banks, and considering that to fully understand how good e-services leads to customer loyalty, the most important 
thing is to analyze the service quality from different aspects rather than emphasizing one of them, the study will be evaluating different factors that customers consider when they are choosing the bank services, hence understand how the quality of Ebanking services leads to customer satisfaction and thus customer's loyalty, and it will also recommend means and ways to get the effectiveness and efficiency of the selected banking services in study area getting improved. Most of the studies displayed that E-banking service quality guide to a very high percentage of satisfied customers. Hence, organizations which adapt best E-banking quality service including, Privacy and Accessibility, Efficiency, Requirement fulfillment can attain a much better chance of earning customer's loyalty.

\section{- Problem Definition}

During the last score, technology took a revolutionary turn, thanks to the huge amount of effort scientists and researchers have put through in order to make our lives easier and somewhat effortless. To reach high standards, banks have to adapt and provide up to date services for their customers, services like E-Banking. Nowadays, E-banking has become an essential service in any bank all around the world, and that is no surprise given the comfort and efficiency it does imply, having so many diverse components and characteristics it has. Electronic banking is poised to get the void filled. According to the competitive world economy nowadays a little difference can be done by many opportunities, but fewer opportunities to get big differences done. Financial organizations and banks can easily make every effort to get all these opportunities seized. This study shows the impact that e-banking quality service has on loyalty of customer through the mediating factor of the satisfaction of customer with the banking sector of the UAE.

\section{- Importance of the Study}

Positive developments in the use of e-banking and the notion of customer satisfaction and loyalty require continued research. Thus, this study provides such a platform. In addition, measures to boost competitiveness of the banking sector can be coined on a better understanding of these aspects. Furthermore, better service delivery and improved customer service are a resultant product of positive developments of these aspects.

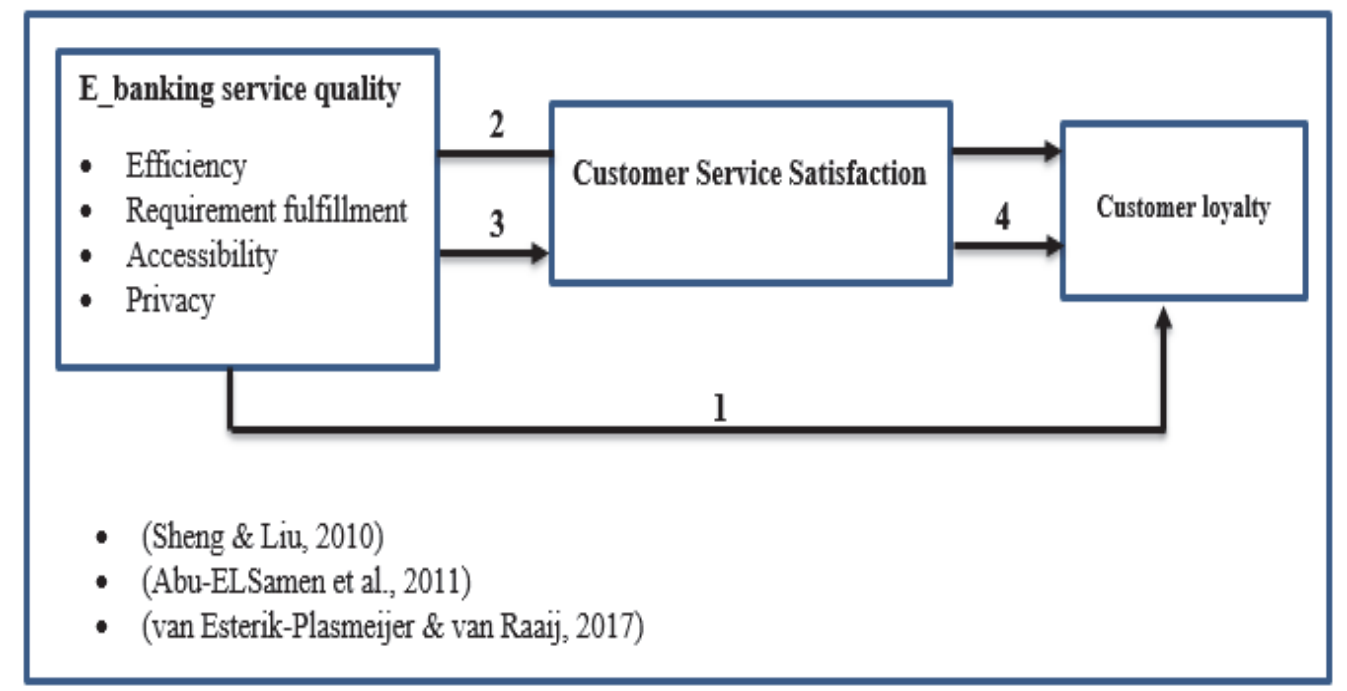

Fig. 1. Research model

- Research Hypotheses:

To achieve research goals and answer its questions, hypotheses were assumed according to theoretical studies linked with Ebanking service quality and customer loyalty.

Hypothesis 1:

- $\quad \mathbf{H}_{1}$ : E-banking service quality (Efficiency, Requirement fulfillment, Accessibility and, Privacy) have a significant impact on customer loyalty.

Hypothesis 2:

- $\quad \mathbf{H}_{2}$ : E-banking service quality mediates the relationship between E-banking service quality and customer loyalty. Hypothesis 3:

- $\quad$ H3$_{3}$ : E-banking service quality have a significant impact on customer service satisfaction. 
Hypothesis 4:

- H4: Customer service satisfaction has a significant impact on customer loyalty.

\section{Literature Review}

\subsection{Introduction}

E-banking has been around for a while since 1983 to be specific, UK was the first country to introduce the E-services in their bank; (NBS) which is Nottingham Building Society launched it, it was not very developed and it had a very small amount of transactions which account holders could benefit from. However, it has set the basics for every internet banking facility that followed. When it was first introduced, e-banking services were not so popular. For instance, $80 \%$ of the banks in the United States introduced Electronic banking services by 2000 to their customers but as an example, it took American bank to acquire 2 million electronic banking service users for about 10 years, though it started to grow rapidly after the Y2K scare has ended. And numbers speak of that growth as estimated in 2009 that only $47 \%$ of US adults and only $30 \%$ of UK adults use online banking services as it was reported by Gartner Group. However, recent studies stated that in most developed countries ebanking is still not so popular and people still prefer old traditional channels. Therefore, the essential factors influencing the adoption and use of electronic banking services that commercial banks provide are important to be understood (Yaseen \& El Qirem, 2018).

\subsection{Challenges Facing Internet Banking}

There is a series an of generic factors that influence the effective ability of a company to successfully adopt e-banking. Notable factors hinge on how the related factors and incorporated into management practices and integrated with other technologies form a 'technology cluster' (Tan, Chew, \& Hamid, 2017). Agbloyor, Abor, Adjasi, \& Yawson, (2014) consider that huge barrier that can undermine such efforts are limited communication infrastructure which is notable in Africa and lack of information. A study by Kant \& Jaiswal (2017) revealed that consumers are reluctant to use internet banking because of the lack of high-quality online banking system infrastructure. Unreliable methods of payments, legal framework, intellectual property rights, unreliable systems, and unreliable security are also some of the critical challenges undermining internet banking (Tang, $\mathrm{Yu}$, Cooke, \& Chen, 2017). The adoption of e-banking is associated with high costs which are either incurred as a result of mandatory and or necessary costs and high e-banking adoption risks (Shankar \& Jebarajakirthy, 2019). Foremost, it is compulsory to obtain regulatory licenses required for all banks which provide internet services to have their remote location licensed. However, lack of cooperation and feeble administration between local administrators and a virtual bank tends to cause an increase in operating costs (Katiyar \& Badola, 2018). According to Katiyar and Badola (2018), the effective adoption of e-banking can be hindered by high e-banking adoption costs which occur as a result of having unestablished obligations by parties involved in a transaction and non-conformance or violation of prescribed practices, regulations, and rules. Despite its high costs, internet banking plays an important role in enhancing the future profitable levels of the bank (Abuhjeeleh, Shamout, Sleimi, \& Harazneh, 2019). Ismail Hussien \& Abd El Aziz, (2013) regard inadequate recovery capabilities, fraudulent actions, hacking incidents, malicious attacks, security shortcomings, control weaknesses, network vulnerabilities, capacity inadequacies, hardware breakdowns, operating mistakes, software defects, processing errors and systems failures are all classified as technology risks. According to Stamenkov and Dika (2015), banks can have their risk profiles developed and examined through the use of information technology developments. (Mäenpää, 2006) noted that banks should have provisions to cater for damages or malfunctions by having standby network, software and hardware components. Yaseen \& El Qirem, (2018) highlighted that considerations for customers' privacy, proof of transactions, validity and legal status of remote banking make it uncertainty to apply technological regulations and laws. According to Stamenkov and Dika, (2015) failure to establish the obligations and legal rights of parties to a transaction and violation of prescribed practices, regulations, rules and laws, is what stirs up legal risk. There can also be some level of uncertainty about the validity of some agreements formed through electronic media and law regarding customer disclosures and privacy protection leads to legal risks in internet banking (Shankar \& Jebarajakirthy, 2019). Customers who have inadequate information about their rights and obligations may not take precautions when using online banking services. This leads to unwanted suits against the bank or other regulatory sanctions and disputed transactions (Albalawi, Naugton, Elayan, \& Sleimi, 2019).

\subsection{Service quality}

Cowling and Newman, (1995) used a SERVQUAL scale to assess how service quality dimensions affect customers' perceptions and expectations. The findings noted that empathy, responsiveness and reliability had major effects on customers' expectations and perceptions. On the other hand, tangibles and empathy had low significant effects on customers' expectations and perceptions. Kant \& Jaiswal, (2017) did a study that used 18 service quality dimensions to examine service quality. These dimensions are security, responsiveness, reliability, integrity, functionality, friendliness, flexibility, courtesy, communication, commitment, comfort, cleanliness, care, availability, attentiveness, aesthetics and access. Kant and Jaiswal (2017) postulated that service quality can be measured by using 6 dimensions namely reliability, service portfolio, tangibles, price, access, assurance and effectiveness. There is an increase interest in research by managers and researchers about ICT technology, its 
applicability in the delivery of financial services and effects on the measurement of service quality (Yaseen \& El Qirem, 2018). The established findings have exhibited mixed perceptions and most do not have a common base of agreement. For instance, a study by Hussien and El Aziz, (2013) considered that online banking service quality can be measured by using they developed the scale for measurement divided into three distinct aspects namely banking service product quality, online system quality and customer service quality. In this research, 17 research items were considered to be empirically invalid. Lee et al. (2017) established that the degree of customer participation, service encounter events and cues in-service setting had significant impacts on service quality. However, the problem is that the employed measurement strategy highlighted above is that it does not have a testable and precise online service quality dimension of online service quality but is rather abstract (AlSudairi, 2016). There are other studies that used the model developed by Parasuraman and others in several countries to the validation of the online service quality scale in the banking industry. Jain and Gupta, (2004) used a multiple-item scale based on the use of an improved SERVQUAL model by Parasuraman and others to assess the e-service quality of online banking. The model constituted credibility, attention, trust, website interface and access as the main determinants of service quality. Siu \& Mou, (2005) admitted that a study of 195 online bank users based developed Hong Kong to develop a measurement scale using an E-SQ instrument, the study outlined that security, problem handling, efficiency and credibility were vital for developing a SERVQUAL measurement model.

\subsection{Customer satisfaction and customer loyalty}

Customer satisfaction is defined as the way an individual feels with regards to pleasure or displeasure emanating from comparisons made between what he or she expects from consuming or using a product and the actual product's outcome (Kotler $\&$ Keller, 2012). Forsythe, (2016) posits that apart from the various approaches that are used to examine customer satisfaction, cyclic surveys can also be used to measure customer satisfaction. Another way that can be used to provide an assessment of customer satisfaction is by examining the customer loss rate (Stamenkov \& Dika, 2015). The company can also use hired people to act as if they are potential buyers and these are known as mystery shoppers. Mishra et al., (2017) contend that mystery shoppers can provide firms with the type of information they need. This information can be related to the disadvantages of buying products from the firm or competitors' and consumers' benefits and shopping experience (AlSudairi, 2016; Sleimi \& Davut, 2015). Thus, they can be said to offer more information about a company's product quality. In the context of online banking services, there are some factors that influence customer satisfaction such as security, responsiveness, accessibility and goodwill (Oh \& Kim, 2017). Moreover, Customer satisfaction has and continues to be a vital pillar of business success (Sleimi, 2020). Mishra, Sinha, \& Koul, (2017) consider satisfaction to be what the consumer feels after weighing what he or she expected from using a product or service against what he or she perceived. Together with marketing strategies, customer satisfaction can be used to examine consumers' expectations of how firms provide goods and services (Al-Hawary, Al-Smeran, \& others, 2017). Customer loyalty influences the significance of the interaction between re-patronage and a person's relative attitude (Stamenkov \& Dika, 2015). Though customer satisfaction plays a crucial role in business management, it does not warrant effective business success on its own. However, it helps to boost the financial position of a company (Mishra et al., 2017). Improvements in loyalty have been noted to be more profitable (Palmer et al., 2013). However, it is most costly to lure new customers than it is to retain prevailing customers (Kotler \& Keller, 2012). Meanwhile, loyal customers can lure more customers to buy from the company and often significantly consider their actions before they decide to buy from other firms. Customer loyalty is not merely obtained but rather it is developed by making good decisions and through sourcing (Dixit \& Datta, 2010). Dufwenberg, (2015) established that establishing good customer relations is essential in enhancing customer loyalty. Coyne and DeLongis, (1986) established that the link between customer loyalty and customer satisfaction is affected by two important things. The first one is when loyalty begins to drop after satisfaction has declined to a certain point. According to Bauer et al.,(2005), the second one is when a dramatic increase in loyalty causes an increase in satisfaction. Most importantly, an increase in customer loyalty and firm performance. Thus, it must be included as part of the business' long-term objectives. Both loyalty and business performance are a function of customer satisfaction (Stamenkov \& Dika, 2015). Loyalty plays a pivotal role in the determination of the business success (Hussien \& El Aziz, 2013; M. T. Sleimi, Karam, \& Qubbaj, 2018). Mostly, loyalty represents a form of behaviour while satisfaction is an attitude. There are ideas which suggest that customer satisfaction helps to place a distinction between initial expectations and perceived service performance (Fraering \& S. Minor, 2013). The success of the company together with the profits that it makes are highly driven by customer satisfaction and loyalty which can be said to be of the main focus of most companies (Yaseen \& El Qirem, 2018). Meanwhile, Dauda \& Lee, (2016) highlighted that customers undergo through various steps before buying products. These steps are awareness, exploration, expansion, commitment, and dissolution. Luz, de Paula, \& de Oliveira, (2018) noted that customer loyalty is a function of customer satisfaction. Lastly, a significant increase in customer satisfaction will trigger a huge increase in loyalty among customers (van Esterik-Plasmeijer \& van Raaij, 2017).

\section{Methodology}

\subsection{Design of the Study and Sampling Technique}

The research relies on the quantitative method and the deductive research approach which have the ability to deal with handle large numbers of variables and dimensions that lead to test and find out conclusions (Henseler \& Sarstedt, 2013). The clients of all banks operating within the Abu Dhabi area are the subjects for this study. According to the population of the study; two steps sampling techniques were used, the researcher relied on cluster sampling and chosen Ras Al Khaimah (RAK) area first 
in a random manner. Again, random sampling techniques have been used to choose 28 branches out-off the 34 branches are working within this geographic area. As the research population is around 150,000 in number according to UAE central bank data for RAK area, the optimal sample size is 384, refer to the Sekaran sample size chart in the appendix (Sekaran, 2006). So, 1500 surveys were distributed to raise the probability of reaching the needed sample size. 397 valid surveys have been collected "greater than the minimum needed" and used for this research with a response rate of $26.5 \%$.

\subsection{Research tool}

An adaptive survey from different prior researches was used as the main tool to gather the needed data regarding research variables. The survey contains 31 statements. The survey was exposing it to five academics and statistical professionals if any necessary adjustments needed. 30 surveys have been distributed and analyzed using SmartPLS software to ensure reliability value, Cronbach's Alpha test value was 0.82 which means an accepted level internal consistency of research tool as it is higher than the minimum accepted level 0.70 (Collis \& Hussey, 2013). For testing respondents' opinions, five scales Likert scale has been used ranging from strongly disagree to strongly agree.

\section{Data Analysis}

\subsection{The initial test for EFA (Exploratory factor analysis)}

After measuring the PLS initial test of the study using the SmartPLS program, the test includes 31 reflective indicators. As can be seen from Fig. 2, 5 reflective (Loy1, Loy4, Sat3, Acc5 and, Eff1) indicators recorded low loading with their related corresponding construct "less than 0.4 ". Deleting those 5 reflective indicators helps to enhance the predictive relevance of the research model that leads to getting more research validity and internal consistency (Sleimi \& Emeagwali, 2017).

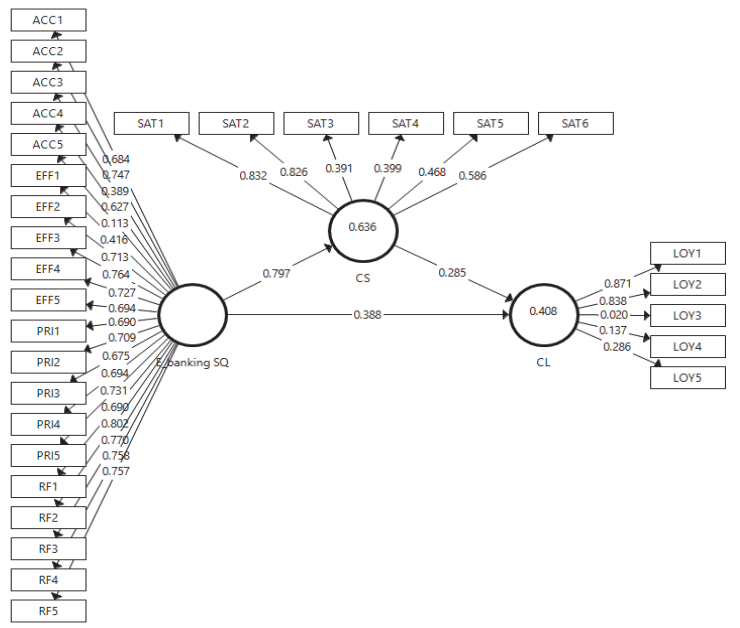

Fig. 2. Research model: the initial Test

\subsection{Research model reliability and validity}

For testing the communality for each reflective indicator with its corresponding construct which means how construct "latent variable" can explain the related indicator. The reliability for each indicator has been shown in the next table, all values are more than 0.4, so this means indicator reliability has been approved (Hulland \& of Business, 1999).

\section{Internal consistency reliability}

Reflective constructs internal consistency need to be assessed depending on the value of composite reliability in (PLS-SEM) taking into account that in reflective models the outer loadings are the wat for assessing the internal consistency parallel with the cut-off point which must be more than 0.7 (F. Hair Jr, Sarstedt, Hopkins, \& G. Kuppelwieser, 2014).

Table 1

Research (CR) Composite Reliability

\begin{tabular}{ll}
\hline Main variable of research & Values of composite reliability \\
\hline CL & .769 \\
CS & .775 \\
E banking SQ & .947 \\
\hline
\end{tabular}

As a conclusion all the above values of composite reliability are more than 0.7 so the composite reliability is definite (Wong \& Kwong, 2013). 
Result of research model convergent validity

According to K. K.-K. Wong, (2013), the Average Variance Extracted Value (AVE) should be estimated for every single construct in order to examine an indicator positive correlation extent with its alternative indicators under the same construct. or let's say it's checking out the construct communality.

Table 2

Testing Average Variance Extracted

\begin{tabular}{ll}
\hline & Average Variance Extracted (AVE) \\
\hline CL & .625 \\
E b banking SQ & .761 \\
\hline
\end{tabular}

AVE values are within the agreeable range whereas all of them are more than 0.5 according to (Joseph F Hair, Ringle, \& Sarstedt, 2013). So, the convergent validity is assured.

Research "discriminant validity"

To demonstrate discriminant validity, the one construct indicators should be highly related to each other and less correlated to other constructs indicators (Wong \& Kwong, 2013). To check the discriminant validity this test has to be fulfilled.

model cross loading analysis

In a way to affirm discriminant validity, cross indicators loadings should be comparatively strong load values over the related corresponding construct in parallel with less load values over the rest constructs which can be easily noticed in a proper pattern (Nitzl, 2016). Table 3 shows the matrix value for cross loadings as a proof of constructs discriminant.

Table 3

$\underline{\text { Research Cross Loading matrix }}$

\begin{tabular}{|c|c|c|c|}
\hline & $\mathbf{C L}$ & $\mathrm{CS}$ & E_banking SQ \\
\hline LOY2 & 0.868 & 0.515 & $0 . \overline{5} 38$ \\
\hline LOY3 & 0.830 & 0.482 & 0.525 \\
\hline LOY5 & 0.837 & 0.272 & 0.261 \\
\hline SAT1 & 0.479 & 0.841 & 0.735 \\
\hline SAT2 & 0.486 & 0.845 & 0.690 \\
\hline SAT4 & 0.183 & 0.723 & 0.271 \\
\hline SAT5 & 0.396 & 0.830 & 0.338 \\
\hline SAT6 & 0.309 & 0.597 & 0.382 \\
\hline ACC1 & 0.423 & 0.473 & 0.688 \\
\hline ACC2 & 0.424 & 0.606 & 0.748 \\
\hline ACC3 & 0.293 & 0.279 & 0.388 \\
\hline $\mathrm{ACC4}$ & 0.419 & 0.490 & 0.622 \\
\hline EFF2 & 0.398 & 0.523 & 0.709 \\
\hline EFF3 & 0.439 & 0.540 & 0.764 \\
\hline EFF4 & 0.511 & 0.577 & 0.724 \\
\hline EFF5 & 0.479 & 0.554 & 0.690 \\
\hline PRI1 & 0.456 & 0.563 & 0.688 \\
\hline PRI2 & 0.436 & 0.657 & 0.715 \\
\hline PRI3 & 0.435 & 0.599 & 0.682 \\
\hline PRI4 & 0.312 & 0.558 & 0.698 \\
\hline PRI5 & 0.461 & 0.692 & 0.731 \\
\hline RF1 & 0.413 & 0.486 & 0.690 \\
\hline RF2 & 0.508 & 0.608 & 0.801 \\
\hline RF3 & 0.476 & 0.614 & 0.774 \\
\hline RF4 & 0.496 & 0.561 & 0.758 \\
\hline RF5 & 0.478 & 0.628 & 0.760 \\
\hline
\end{tabular}

\section{Fornell and Larcker test}

This test is also recommended to affirm the discriminant validity between research constructs. Wong and Kwong, (2013) stated that the square root of the Average Variance Value (AVE) of each construct must be higher than the value of its correlation with others to assure its discriminant. Table 4 represents positively supporting results of this test as discriminant validity demonstration.

\section{Table 4}

Fornell and Larcker Criterion1

\begin{tabular}{llll}
\hline & CL & CS & E banking SQ \\
\hline CL & 0.815 & & \\
CS & 0.694 & 0.797 & \\
E_banking SQ & 0.559 & 0.612 & 0.677 \\
\hline
\end{tabular}


The Heterotrait-Monotrait Ratio of Correlations (HTMT)

According to the structural equation modeling (variance-based), the discriminant validity estimation process mostly depends on HTMT standard which tells that if the value of HTMT is less than 0.90 among the two reflective constructs then their discriminant validity is definite (Henseler, Ringle, \& Sarstedt, 2015). Table 5 displays HTMT accepted values whereas all of them are less than 0.90 so discriminant validity is proved for all constructs.

Table 5

Heterotrait-Monotrait Ratio (HTMT)

\begin{tabular}{|c|c|c|c|}
\hline & $\mathrm{CL}$ & $\mathrm{CS}$ & E_banking SQ \\
\hline \multicolumn{4}{|l|}{$\mathrm{CL}$} \\
\hline $\mathrm{CS}$ & 0.786 & & \\
\hline E banking SQ & 0.642 & 0.518 & \\
\hline
\end{tabular}

\section{Research Relevance for Outer Model}

Bootstrapping mechanism is a doubtless method used to examine the importance of formative constructs outer weights, these case outcomes marked out that at a significance level of $\alpha=5 \%$ all outer weights of formative indicators, are significant since their T-statistic values are higher than 1.96 and their $p$ values are lower than 0.05 (Joe F Hair, Ringle, \& Sarstedt, 2011). Table 6 expounds the bootstrapping outcomes for outer weights.

Table 6

Bootstrapping Results for the Outer Weights

\begin{tabular}{|c|c|c|c|c|c|}
\hline & Original Sample $(\mathrm{O})$ & Sample Mean (M) & Standard Deviation (STDEV) & T Statistics $(|\mathrm{O} / \mathrm{STDEV}|)$ & P Values \\
\hline $\mathrm{CS} \rightarrow \mathrm{CL}$ & 0.262 & 0.263 & 0.084 & 3.102 & 0.002 \\
\hline E_banking SQ $\rightarrow$ CL & 0.413 & 0.414 & 0.083 & 4.964 & 0.000 \\
\hline E banking SQ $\rightarrow$ CS & 0.797 & 0.798 & 0.027 & 30.002 & 0.000 \\
\hline
\end{tabular}

\subsection{Analysis of multicollinearity for research model}

Table 7 presents the VIF values which are less than 5 in a sign of no Multicollinearity problem between the formative indicators (Joe F Hair et al., 2011).

Table 7

Variance Inflation Factor (VIF) values

\begin{tabular}{llll}
\hline & Customers Loy & Customers Sat & E_banking SQ \\
\hline Customers Loy & & & \\
Customers Sat & 1.751 & 1.000 & \\
E_banking SQ & 1.751 & & \\
\hline
\end{tabular}

\section{Research multicollinearity measurement}

The cut-off point of VIF values is 5, values less than the cot-off point is accepted which means the exogenous variable can predict the related endogenous one (Hair et al., 2011). By looking at the following table, all three needed values are less than 5 that indicates the structural model has no multicollinearity problem.

\section{Table 8}

The values of VIF for research variables

\begin{tabular}{lll}
\hline & CL & CS \\
\hline CL & & \\
CS & 1.716 & \\
E_banking SQ & 1.642 & 2.184 \\
\hline
\end{tabular}

4.4 Examining research model fit

For testing research model fit, SRMR value is the clue, this value in fact represents the standardized root mean square residual that generated from the actual correlation matrix (Joseph F Hair et al., 2013). This test usually used to be sure about the vacancy of model misspecification, this value must be less than 0.08 to confirm good model fit (Sarstedt, Ringle, Smith, Reams, \& Hair, 2014). Research model approved good fit as SRMR value is 0.063 .

\section{Testing the predictive relevance of research model}

\section{Coefficient of determination $\left(R^{2}\right)$}

For research model, the value for the endogenous latent variable CS is 0.636 "see graph (4.9)". As there is only one related exogenous variable for the CS which is E_banking SQ, this means that E_banking SQ explain 63.6\% of the total variance in CS (Sarstedt et al., 2014). Moreover, the value of $\mathrm{R}^{2}$ for the endogenous latent variable intention to use (CL) is 0.412 , this indicates that the two related exogenous variables (E_banking SQ, CS) reasonably explain $41.2 \%$ of the total variance in CL. 
Table 9

The results of $\mathrm{R}^{2}$ and Adjusted $\mathrm{R}^{2}$

\begin{tabular}{ll}
\hline & R Square \\
\hline $\mathrm{CL}$ & 0.412 \\
$\mathrm{CS}$ & 0.636 \\
\hline
\end{tabular}

Examining the effect size $\left(f^{2}\right)$

Table 10 shows the effect size $\left(\mathbf{f}^{2}\right)$ of dropping any of the exogenous variables that explain the endogenous variable in the structural model (CL).

Table 10

The results of $\mathrm{F}^{2}$ values

\begin{tabular}{llll}
\hline & CL & CS & E_banking SQ \\
\hline CL & & & \\
CS & 0.406 & & \\
E_banking SQ & 0.026 & 10.853 & \\
\hline
\end{tabular}

The results showed that E_banking SQ has a small effect size over CL and high effect size over CS since the $\mathrm{f}^{2}$ cutoff values for small effect size is $(0.02)$, and for large effect size is $(0.3)$ (Garson, 2016). For CS, the $\mathrm{f}^{2}$ value indicating high effect size for dropping it on the $\mathrm{R}^{2}$ for $(\mathrm{CL})$.

Measuring model "cross validated redundancy $\left(Q^{2}\right)$ ”

Table 11

Cross-validated redundancy $(\mathrm{Q} 2)$

\begin{tabular}{llll} 
& & SSE & $\mathrm{Q}^{2}(=1-\mathrm{SSE} / \mathrm{SSO})$ \\
\hline CL & SSO & 671.731 & 0.209 \\
CS & 849.000 & $1,061.444$ & 0.250 \\
E banking SQ & $1,415.000$ & $5,094.000$ & \\
\hline
\end{tabular}

As the $Q^{2}$ values for research endogenous variables CS and CL are; “ 0.250 and 0.209 ” respectively. The cut-off point s zero, greater than this value indicates that the research model has suitable predictive relevance regarding the endogenous latent variables CS and CL (Wong, 2013).

\subsection{SEM Structural equation model}

Fig. 3 illustrates SEM path coefficients between research variables in conjunction with all loadings of reflective indictors.

\subsection{Interpretation of path Coefficients for research model}

The idea of PLS-SEM is do depend on standardized regression coefficients that relying on standard deviation value of each single variable of the research. Here, it's necessary to look at the values on the arrows between research variables to conduct the amount of the direct effect of each exogenous $\backslash$ independent variable on the dependent $\backslash$ endogenous variable (Jakobowicz, 2006). As a result, the interpretations research variables coefficients would be as follow:

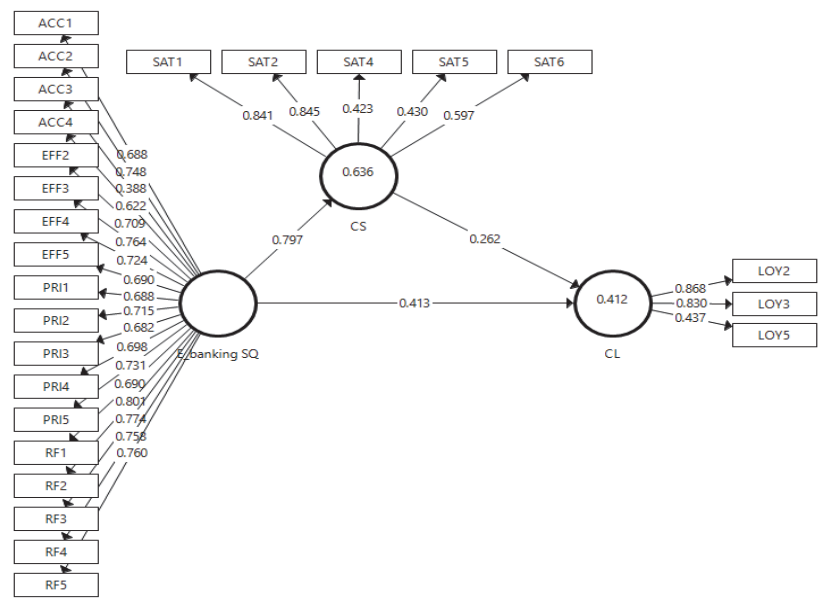

Fig. 3. The Structural Equation Model 
E_banking SQ $\rightarrow$ CS: When E_banking raises by only one value in it's standard deviation, this can leads to a growth of CS standard deviation of 0.797 if the rest variables effects have been neutralized.

$\mathbf{C S} \rightarrow \mathbf{C L}:$ When CS raises by only one value in it's standard deviation, this can leads to a growth of CL standard deviation of 0.262 if the rest variables effects have been neutralized.

E_banking SQ $\rightarrow$ CL: When E_banking raises by only one value in it's standard deviation, this can leads to a growth of CL standard deviations of 0.413 if the rest variables effects have been neutralized.

\section{Significance of path coefficients}

This result includes in addition to the path coefficients; the direct and indirect effects between research variables, outer weight and, outer loadings, means and standard deviations etc., (Henseler et al., 2015). Table 12 shows the T-statistics for the Path Coefficients using Bootstrapping methods.

Table 12

T-statistics for the Path Coefficients

\begin{tabular}{lcccc}
\hline & $\begin{array}{c}\text { Original } \\
\text { Sample (O) }\end{array}$ & $\begin{array}{c}\text { Sample } \\
\text { Mean (M) }\end{array}$ & $\begin{array}{c}\text { Standard Deviation } \\
\text { (STDEV) }\end{array}$ & $\begin{array}{c}\text { T Statistics } \\
(\mid \mathbf{O} / \text { STDEV } \mid \text { ) }\end{array}$ \\
\hline CS $\rightarrow$ CL & 0.262 & 0.263 & 0.084 & 3.102 \\
E_banking SQ $\rightarrow$ CL & 0.413 & 0.414 & 0.083 & 0.002 \\
E_banking SQ $\rightarrow$ CS & 0.797 & 0.798 & 0.027 & 0.000 \\
\hline
\end{tabular}

Bootstrapping result shows that the whole path coefficients among research model is statistically significant as follow:

- The path coefficients between exogenous variable E_banking SQ and the endogenous variable CS at $\alpha=5 \%$ is statistically significant as the value of T-Statistics is more than 1.96 and $\mathrm{p}$-values is lower than 0.05 .

- The path coefficients between exogenous variable E_banking SQ and the endogenous variable CL at $\alpha=5 \%$ is statistically significant as the value of T-Statistics is more than 1.96 and p-values is lower than 0.05 .

- The path coefficients between exogenous variable CS and the endogenous variable CL at $\alpha=5 \%$ is statistically significant as the value of T-Statistics is more than 1.96 and p-values is lower than 0.05 .

So, this results means that all path coefficients in the research model are statistically significant.

\section{Analysis of model mediation variable effect}

The clue of the mediating relationships within research model is to take into account the indirect effects of some exogenous variables from precession relationships in the model, which subsequently utilize the key dependent variable by the mediator variable (Nitzl, 2016). For research model, (CS) mediates the indirect effects of both E_banking SQ that represents main exogenous variable and the man endogenous constructs CL. The result of the mediating effect is shown in Table 13.

Table 13

Indirect Effects

\begin{tabular}{lll}
\hline & E banking SQ & CS \\
\hline E_banking SQ & & CL \\
CS & & \\
CL & & \\
\hline
\end{tabular}

As path coefficients result indicates direct relationships between E_banking SQ and CL previously at this part, it is necessary to look at the total effect "direct and indirect effects" between these two variables. Table 14 indicates the total effect.

Table 14

Total Effects

\begin{tabular}{llll}
\hline & Direct Effect & Indirect Effect & Total Effect \\
\hline E_banking SQ $\rightarrow$ CL & 0.413 & 0.209 & 0.622 \\
\hline
\end{tabular}

The total effect can be computed by aggregating the values of direct and indirect impact together. Consequently, T-statistics for the direct and indirect effects using Bootstrapping method in SmatPLS program are shown in Table 15. The path coefficients results indicate the following; the indirect relationships between E_banking SQ and CL by CS is statistically significant at $\alpha=5 \%$ is as the value of T-Statistics is more than 1.96 and p-values is lower than 0.05 , so the indirect effect has been confirmed. When getting significant direct and indirect effects, this means the mediating variable has partially mediating impact among the exogenous and endogenous variables (K. K.-K. Wong, 2013). This leads to this result; CS is partially mediating the relationships between E_banking SQ and CL. 
Table 15

$\underline{T}$ _test summary for indirect $\backslash$ direct impact

\begin{tabular}{|c|c|c|c|c|}
\hline & $\begin{array}{l}\text { Original } \\
\text { Sample (O) }\end{array}$ & $\begin{array}{l}\text { Standard } \\
\text { Deviation (STDEV) }\end{array}$ & $\begin{array}{l}\text { T Statistics } \\
(\mid \text { O/STDEV } \mid)\end{array}$ & P Values \\
\hline \multicolumn{5}{|c|}{$\underline{\text { Direct effects }}$} \\
\hline E_banking SQ $\rightarrow C L$ & 0.413 & 0.083 & 4.964 & 0.000 \\
\hline \multicolumn{5}{|c|}{ Indirect effects } \\
\hline E_banking SQ $\rightarrow$ CL & 0.209 & 0.210 & 8.069 & 0.002 \\
\hline
\end{tabular}

\subsection{Hypotheses test results}

The following table summarizes the hypotheses test results

Table 1

The hypotheses test results

\begin{tabular}{lll}
\hline Number & Hypothesis & Decision \\
\hline Hypothesis one $\mathbf{H}_{\mathbf{1}}$ & $\begin{array}{l}\text { H1: E-banking service quality (Efficiency, Requirement fulfillment, Accessibility } \\
\text { and, Privacy) have a significant impact on customer loyalty. }\end{array}$ & Supported \\
Hypothesis two $\mathbf{H}_{\mathbf{1}}$ & $\begin{array}{l}\text { H1: E-banking service quality mediates the relationship between E-banking service } \\
\text { quality and customer loyalty. }\end{array}$ & Supported \\
Hypothesis three $\mathbf{H}_{\mathbf{1}}$ & $\begin{array}{l}\text { H1: E-banking service quality have a significant impact on customer service satis- } \\
\text { faction. }\end{array}$ & Supported \\
Hypothesis four $\mathbf{H}_{\mathbf{1}}$ & H1: Customer service satisfaction has a significant impact on customer loyalty. & Supported \\
\hline
\end{tabular}

\section{Discussion of Findings}

The main objective was to examine the effects of using electronic banking on customer loyalty mediated by customer satisfaction. This included examining both the direct and indirect effects of e-banking on satisfaction of customer. The study findings have reiterated that a direct relationship existed between E_banking service quality and customer loyalty. Moreover, E_banking service quality had an indirect significant relationship on customer loyalty. Consequently, as the direct and indirect impact have been approved, the customer satisfaction partially mediated the E banking service quality impact over customer loyalty. As research findings admitted that there is an indirect significant path between E_banking service quality and customer loyalty through customer satisfaction, and there was a direct significant path between E_banking service quality and customer loyalty. This approved that customer satisfaction partially mediate the relationship between E_banking service quality and customer loyalty. However, the direct impact of E_banking service quality on customer loyalty through customer satisfaction was higher than the indirect effect. This indicates that looking just for E_banking service quality and forgetting customer satisfaction is not enough as they are needed to be considered together to attain best level of customer loyalty. The outcomes of this study have shown that when E_banking raises by value of one standard deviation from its mean it can lead to a growth in customer satisfaction standard deviations by 0.797 from its mean if the rest variables effects have been neutralized. If customer satisfaction raises by value of one standard deviation from its mean it can lead to a growth in customer loyalty standard deviations by 0.262 from its mean if the rest variables effects have been neutralized. Lastly, E_banking raised by value of one standard deviation from its mean which can lead to a growth in customer loyalty standard deviations by 0.413 from its mean if the rest variables effects have been neutralized. To sum up, it's important to include that E-banking is an innovative more that is targeted at improving the quality of services offered by banks. Of which the prime focus of e-banking is to introduce more services and products that can lure more customers to use the bank's products and services. Shankar and Jebarajakirthy, (2019) concurs with this idea and posit that e-banking is a competitive move that is aimed at intensifying competition in a manner that lures customers and increase revenue inflow by increasing the banks' services range.

\subsection{Recommendations}

In line with the provided findings, the study recommends the following possible strategies and/or measures; Banks must offer e-banking services that are accessible, efficient and do not compromise customers' privacy but rather fulfill the required purposes or customer needs for banks' management and it is important to develop other products and services that complement the use of e-banking as a hedging strategy to help maintain customer satisfaction levels high. This is important because it acts as a provision in case e-banking fails to yield the desired results. There is a need to preserve a bank's status quo and reputation by ensuring that e-banking and other banking services help customers maintain positive perceptions towards the banks. In addition, banks must engage in market research so as to ensure that the type of e-banking services they offer are up to date and, in a position, to fulfill customers' requirements or needs.

\subsection{Limitations, contributions, and Suggestions for future studies}

The limited time frame for this study compelled the researchers to settle for results based on ideas collected from banks' customers in Ras Al Khaimah city in the UAE and hence, the results of this study might not be generalized to apply in other industries and countries. That being said, future studies can extend this research by analyzing these variables for Islamic and national banks and clarify the differences between them or by extending their sample to cover the whole UAE sector instead 
of one city which is RAK in this research. The benefits of this research exceed the UAE banking sector and it will be beneficial for other Gulf countries which are somehow similar to UAE according to their culture and economic conditions. furthermore, study results will be beneficial for academics and researchers as it gives practical implications for further researches as it provided fitted conceptual model which linking e-banking service quality and customer loyalty. This study offers a share to the existing knowledge regarding E-banking service quality and its relationship with customer loyalty by identifying the main service quality dimensions, and how all these dimensions can affect customer loyalty. Nevertheless, E-banking service quality and its relationship with customer loyalty have not been mentioned in the same mechanism in literature researches in UAE.

\section{Acknowledgement}

This paper was financially supported by the Palestine Technical University - Kadoorie and the authors would like to express their gratitude for this funding.

\section{References}

Abuhjeeleh, M., Shamout, M. D., Sleimi, M. T., \& Harazneh, I. (2019). Destination Marketing for Expatriates: A Case Study in Northern Cyprus. African Journal of Hospitality, Tourism and Leisure, 8(3), 201-219.

Agbloyor, E. K., Abor, J. Y., Adjasi, C. K. D., \& Yawson, A. (2014). Private capital flows and economic growth in Africa: The role of domestic financial markets. Journal of International Financial Markets, Institutions and Money, 30, $137-152$.

Al-Hawary, S. I. S., Al-Smeran, W. F., \& others. (2017). Impact of Electronic Service Quality on Customers Satisfaction of Islamic Banks in Jordan. International Journal of Academic Research in Accounting, Finance and Management Sciences, 7(1), 170-188.

Albalawi, A. S., Naugton, S., Elayan, M. B., \& Sleimi, M. T. (2019). Perceived Organizational Support, Alternative Job Opportunity, Organizational Commitment, Job Satisfaction and Turnover Intention: A Moderated-mediated Model. Organizacija, 52(4), 310-324.

AlSudairi, M. A. T. (2016). E-service quality strategy: Achieving customer satisfaction in online banking. Journal of Theoretical and Applied Information Technology, 38(1), 6-24.

Bauer, H. H., Hammerschmidt, M., \& Falk, T. (2005). Measuring the quality of e-banking portals. International Journal of Bank Marketing, 23(2), 153-175. https://doi.org/10.1108/02652320510584395

Collis, J., \& Hussey, R. (2013). Business research: A practical guide for undergraduate and postgraduate students. Palgrave macmillan.

Cowling, A., \& Newman, K. (1995). Banking on people: TQM, service quality and human resources. Personnel Review, $24(7), 25-40$.

Coyne, J. C., \& DeLongis, A. (1986). Going beyond social support: The role of social relationships in adaptation. Journal of Consulting and Clinical Psychology, 54(4), 454.

Dauda, S. Y., \& Lee, J. (2016). Quality of service and customer satisfaction: a conjoint analysis for the Nigerian bank customers. International Journal of Bank Marketing, 34(6), 841-867.

Dixit, N., \& Datta, S. K. (2010). Customers perception on internet banking and their impact on customer satisfaction and loyalty: A study in Indian context. Journal of Computing, 2(7), 131-135.

Dufwenberg, M. (2015). Banking on experiments? Journal of Economic Studies, 42(6), 943-971. https://doi.org/10.1108/JES08-2015-0145

F. Hair Jr, J., Sarstedt, M., Hopkins, L., \& G. Kuppelwieser, V. (2014). Partial least squares structural equation modeling (PLS-SEM) An emerging tool in business research. European Business Review, 26(2), 106-121.

Forsythe, P. J. (2016). Construction service quality and satisfaction for a targeted housing customer. Engineering, Construction and Architectural Management, 23(3), 323-348. https://doi.org/10.1108/ECAM-05-2015-0076

Fraering, M., \& S. Minor, M. (2013). Beyond loyalty: customer satisfaction, loyalty, and fortitude. Journal of Services Marketing, 27(4), 334-344.

Hair, Joe F, Ringle, C. M., \& Sarstedt, M. (2011). PLS-SEM: Indeed a silver bullet. Journal of Marketing Theory and Practice, 19(2), 139-152.

Hair, Joseph F, Ringle, C. M., \& Sarstedt, M. (2013). Editorial-partial least squares structural equation modeling: Rigorous applications, better results and higher acceptance. Long Range Planning, 46(1-2), 1-12.

Henseler, J., Ringle, C. M., \& Sarstedt, M. (2015). A new criterion for assessing discriminant validity in variance-based structural equation modeling. Journal of the Academy of Marketing Science, 43(1), 115-135.

Henseler, J., \& Sarstedt, M. (2013). Goodness-of-fit indices for partial least squares path modeling. Computational Statistics, $28(2), 565-580$.

Hulland, J., \& of Business, R. I. S. (1999). Use of partial least squares (PLS) in strategic management research: A review of four recent studies. Strategic Management Journal, 20(2), 195-204.

Hussien, M. I., \& El Aziz, R. A. (2013). Investigating e-banking service quality in one of Egypt's banks: A stakeholder analysis. TQM Journal, 25(5), 557-576. https://doi.org/10.1108/TQM-11-2012-0086

Ismail Hussien, M., \& Abd El Aziz, R. (2013). Investigating e-banking service quality in one of Egypts banks: a stakeholder analysis. The TQM Journal, 25(5), 557-576.

Jain, S. K., \& Gupta, G. (2004). Measuring service quality: SERVQUAL vs. SERVPERF scales. Vikalpa, $29(2), 25-38$.

Jakobowicz, E. (2006). Understanding PLS path modeling parameters estimates: a study based on Monte Carlo simulation and customer satisfaction surveys. COMPSTAT 2006, 17th Symposium on Computational Statistics, Rome, $721-728$. 
Kant, R., \& Jaiswal, D. (2017). The impact of perceived service quality dimensions on customer satisfaction. International Journal of Bank Marketing, 35(3), 411-430. https://doi.org/10.1108/ijbm-04-2016-0051

Katiyar, R., \& Badola, S. (2018). Modelling the barriers to online banking in the Indian scenario: an ISM approach. Journal of Modelling in Management, 13(3), 550-569. https://doi.org/10.1108/JM2-01-2018-0006

Kotler, P., \& Keller, K. (2012). Dirección de marketing (Decimocuarta ed.). Naucalpan de Juárez: Pearson Education.

Lee, J. (Jiyeon), Patterson, P. G., \& Ngo, L. V. (2017). In pursuit of service productivity and customer satisfaction: the role of resources. European Journal of Marketing, 51(11-12), 1836-1855. https://doi.org/10.1108/EJM-07-2016-0385

Luz, C. M. D. R., de Paula, S. L., \& de Oliveira, L. M. B. (2018). Organizational commitment, job satisfaction and their possible influences on intent to turnover. REGE Revista de Gest\{ãa $\} o, 25(1), 84-101$.

Mäenpää, K. (2006). Clustering the consumers on the basis of their perceptions of the Internet banking services. Internet Research, 16(3), 304-322.

Mansumitrchai, S., \& Chiu, C. (2012). Adoptation of Internet banking in UAE: factors underlying adoption characteristics. International Journal of Management and Marketing Research, 5(1), 103-115.

Mishra, H. G., Sinha, P. K., \& Koul, S. (2017). Customer dependence and customer loyalty in traditional and modern format stores. Journal of Indian Business Research, 9(1), 59-78. https://doi.org/10.1108/JIBR-12-2015-0126

Nitzl, C. (2016). The use of partial least squares structural equation modelling (PLS-SEM) in management accounting research: Directions for future theory development. Journal of Accounting Literature, 37, 19-35.

Oh, H., \& Kim, K. (2017). Customer satisfaction, service quality, and customer value: years 2000-2015. International Journal of Contemporary Hospitality Management, 29(1), 2-29.

Palmer, S. L., Armstrong, C., Onar-Thomas, A., Wu, S., Wallace, D., Bonner, M. J., ... others. (2013). Processing speed, attention, and working memory after treatment for medulloblastoma: an international, prospective, and longitudinal study. Journal of Clinical Oncology, 31(28), 3494.

Sarstedt, M., Ringle, C. M., Smith, D., Reams, R., \& Hair, J. F. (2014). Partial least squares structural equation modeling (PLS-SEM): A useful tool for family business researchers. Journal of Family Business Strategy, 5(1), $105-115$.

Sekaran, U. (2006). Research methods for business: A skill building approach. John Wiley \& Sons.

Shankar, A., \& Jebarajakirthy, C. (2019). The influence of e-banking service quality on customer loyalty. International Journal of Bank Marketing, IJBM-03-2018-0063. https://doi.org/10.1108/IJBM-03-2018-0063

Siu, N. Y.-M., \& Mou, J. C.-W. (2005). Measuring service quality in internet banking: the case of Hong Kong. Journal of International Consumer Marketing, 17(4), 99-116.

Sleimi, M. (2020). Effects of risk management practices on banks' performance: An empirical study of the Jordanian banks. Management Science Letters, 10(2), 489-496.

Sleimi, M. T., \& Davut, S. (2015). Intrinsic and Extrinsic Motivation: Pivotal Role in Bank Tellers Satisfaction and Performance: Case Study of Palestinian Local Banks. International Journal of Business and Social Science, 6(11), $127-136$.

Sleimi, M. T., \& Emeagwali, O. L. (2017). Do employee attitudes mediate the relationship between strategic human resource management practices and organizational effectiveness? A SEM based investigation using SMART-PLS software. Business and Economic Horizons (BEH), 13(1232-2017-2403), 42.

Sleimi, M. T., Karam, A. A., \& Qubbaj, I. S. (2018). The Impact of E-Banking Services Quality on Customers Satisfaction Moderated by Customer Trust: Survey on Arab Bank in Amman, Jordan. Journal of Al-Quds Open University for Administrative \& Economic Research, 3(9).

Stamenkov, G., \& Dika, Z. (2015). A sustainable e-service quality model. Journal of Service Theory and Practice, 25(4), 414-442.

Tan, L. H., Chew, B. C., \& Hamid, S. R. (2017). Service quality implementation in shaping sustainable banking operating system: A case study of Maybank Group. Qualitative Research in Financial Markets, 9(4), 359-381.

Tang, G., Yu, B., Cooke, F. L., \& Chen, Y. (2017). High-performance work system and employee creativity: The roles of perceived organisational support and devolved management. Personnel Review, 46(7), 1318-1334.

van Esterik-Plasmeijer, P. W. J., \& van Raaij, W. F. (2017). Banking system trust, bank trust, and bank loyalty. International Journal of Bank Marketing, 35(1), 97-111.

Wong, K. K.-K. (2013). Partial least squares structural equation modeling (PLS-SEM) techniques using SmartPLS. Marketing Bulletin, 24(1), 1-32.

Wong, K. K. K., \& Kwong, K. (2013). Partial Least Squares Structural Equation Modeling (PLS-SEM) Techniques Using Smart PLS. Marketing Buletin.

Yaseen, S. G., \& El Qirem, I. A. (2018). Intention to use e-banking services in the Jordanian commercial banks. International Journal of Bank Marketing, 36(3), 557-571. https://doi.org/10.1108/IJBM-05-2017-0082

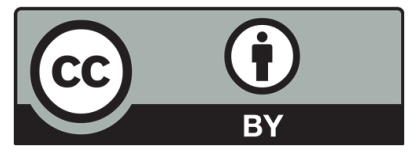

(C) 2020 by the authors; licensee Growing Science, Canada. This is an open access article distributed under the terms and conditions of the Creative Commons Attribution (CC-BY) license (http://creativecommons.org/licenses/by/4.0/). 